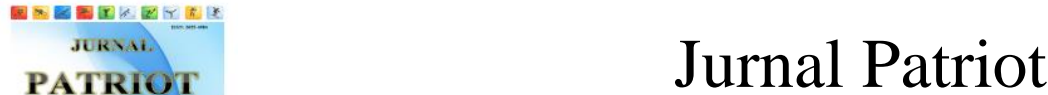

ISSN Online: 2714-6596 ISSN Cetak: 2655-4984

Home: http://patriot.ppj.unp.ac.id/index.php/patriot

Volume 3 Nomor 3 Tahun 2021 (Halaman 223-232)

DOI: $10.24036 /$ patriot.v\%vi\%i.736

\section{Minat Peserta Didik Kelas XI terhadap Proses Pembelajaran Renang}

\author{
Syifa Fahmi Ramadhan ${ }^{1}$, Heru Syarli Lesmana ${ }^{2 *}$, Tjung Hauw Sin ${ }^{3}$, Naluri Denay ${ }^{4}$ \\ 1,2,3,4Program Studi Pendidikan Kepelatihan Olahraga, Fakultas Ilmu Keolahragaan, Universitas \\ Negeri Padang, Indonesia. \\ Email Korespondensi: fahmi160198@gmail.com
}

\author{
Informasi Artikel: \\ Dikirim: 20 November 2020 Direvisi: 8 Maret 2021 Diterbitkan: 1 September 2021
}

\begin{abstract}
ABSTRAK
Olahraga renang dalam proses pendidikan diartikan sebagai upaya yang diberikan pada peserta didik untuk mengembangkan potensi yang dimiliki peserta didik. Permasalahan yang terdapat pada penelitian ini adalah rendahnya minat peserta didik kelas XI di SMA Negeri 7 Padang dalam kegiatan pembelajaran olahraga renang. Tujuan dari penelitian ini untuk melihat seberapa minat dari setiap peserta didik dalam pembeajaran olahraga renang. Jenis penelitian yang digunakan adalah penelitian deskriptif. Penelitian ini dilaksanakan di SMA Negeri 7 Padang pada bulan Agustus dan September 2020. Jumlah populasi adalah 324 orang pada tahun ajaran 2020/2021. Teknik pengambilan data yang digunakan ialah teknik simple random sampling. Sampel dalam penelitian ini berjumlah 65 orang peserta didik yang dijadikan sampel dari setiap kelas XI IPA dan IPS. Instrumen pengambilan data dilakukan melalui pembagian angket pada peserta didik. Hasil penelitian menunjukkan minat peserta didik dalam pembelajaran olahraga renang termasuk di klasifikasi "kuat/baik" $(78,20 \%)$. Hal ini sejalan dengan hasil wawancara dimana peserta didik memiliki minat yang tinggi terhadap pembelajaran renang. Namun nilai yang didapatkan masih berada dibawah KKM dikarenakan beberapa faktor seperti kurangnya pemahaman peserta didik terhadap materi dan kurang tepatnya metode pembelajaran yang digunakan guru pada proses pembelajaran. Olah karena itu, dalam penelitian ini diharapkan proses pembelajaran dapat meningkat minat dari peserta didik dalam belajar olahraga renang.
\end{abstract}

Kata kunci: renang; minat belajar; deskriptif.

\section{Class XI Students' Interest in Swimming Learning Process}

\begin{abstract}
Swimming in the educational process is defined as an effort given to students to develop the potential of students. The problem in this study is the low interest of class XI students at SMA Negeri 7 Padang in swimming sports learning activities. The purpose of this study was to see how interested each student was in teaching swimming. The type of research used is descriptive research. This research was conducted at SMA Negeri 7 Padang in August and September 2020. The total population was 324 people in the 2020/2021 school year. The data collection technique used is simple random sampling technique. The sample in this study amounted to 65 students who were sampled from each class XI Science and Social Sciences. The data collection instrument was carried out through the distribution of questionnaires to students. The results showed that the students' interest in learning swimming was included in the "strong/good" classification (78.20\%). This is in line with the results of interviews where students have a high interest in learning to swim. However, the value obtained is still below the KKM due to several factors such as the lack of students' understanding of the material and the lack of precise learning methods used by the teacher in the learning process. Therefore, in this
\end{abstract}


study, it is hoped that the learning process can increase the interest of students in learning swimming.

Keywords: swimming; interest to learn; descriptive.

\section{PENDAHULUAN}

Pendidikan jasmani merupakan salah satu pendukung untuk meningkatkan pertumbuhan dan perkembangan bagi peserta didik (Maidarman, 2010). Salah satu bentuk pendidikan jasmani adalah olahraga renang. Menurut Syahputra \& Arwandi (2014) olahraga renang merupakan cabang olahraga yang memiliki banyak manfaat salah satunya bagi kesehatan tubuh dan menjadi pengisi waktu luang untuk rekreasi. Selain itu olahraga renang merupakan salah satu cabang olahraga prestasi, dalam pencapaian prestasi setiap atlet harus memiliki motivasi dalam dirinya karena motivasi tersebut adalah dasar bagi setiap atlet yang ingin berprestasi (Wahyudi, 2019).

Olahraga renang merupakan aktivitas yang dilakukan di alam yang memiliki keunggulan untuk fisik dan psikologis, serta meningkatkan semua faktor dalam meningkatkan kesehatan mental (Tavakolizadeh, 2012). Perkembangan olahraga renang sangat berkembang dengan berkesinambungan dikarenakan olahraga dapat meningkatkan fisik dan mental pada seseorang (Masrun, 2016). Olahraga renang ini juga dilakukan didalam air dengan cara menggerakan bagian organ tubuh sehingga mendapatkan gerakan meju kedepan (Maidarman, 1999). Oleh karena itu perkembangan olahraga renang dari segi prestasi cukup baik. Berdasarkan kejuaraan Pekan Olahraga Nasional XVII tahun 2012, atlet Sumatera Barat pada cabang olahraga renang mendapatkan juara di kejuaran tersebut. Namun di kejuaran Pekan Olahraga Nasional (PON) tahun 2016 atlet Sumatera Barat tidak mendapat juara di bidang olahraga renang. Kota Padang telah berupaya melakukan pembinaan, baik pembinaan yang dilakukan di sekolah maupun di perkumpulan $(c l u b)$ renang dimana setiap pelatih memiliki strategi dalam pembelajarannya dimana yang dilihat mulai dari teknik dalam gerakan (Krisna, 2008) selain itu yang harus diperhatikan dari bagian organtubuh dalam dimana pada saluran pembulu darah, jantung sampai ke seluruh otot yang bekerja (Sato, 2020). Menurut Putra \& Lesmana (2016) prestasi olahraga seorang atlet haruslah terus berlatih agar mencapai hasil yang maksimal, namun berlatih tanpa pemulihan tidak akan mencapai hasil yang maksimal, karena mereka hanya meningkatkan aspek penampilan tanpa mengatasi kelelahan yang terjadi. Dalam peningkatan prestasi olahraga, banyak faktor yang mempengaruhi untuk mencapai prestasi renang secara maksimal (Lankia et al., 2019). Olahraga ini sangat kompleks tetapi dapat diukur, kemampuan berenang dapat dilakukan berdasarkan kecepatan waktu tempuh dalam melakukan teknik yang sesuai dan salah satu teknik yang berpengaruh dalam kecepatan yaitu luncuran dalam renang (Siregar \& Syahara, 2019). Menurut Maulani (2011) menyatakan bahwasannya minat datang dari dalam diri seseorang yang didorong oleh motivasi.

Pendidikan olahraga menjadi pendidikan berintegral dimana proses pendidikan sebagai bidang paedagogis dalam gerakan dan pengalaman dalam bergerak (Ilham, 2016). Oleh karena itu peneliti melakukan observasi lapangan dimana hasil dalam 
kegiatan pembelajaran pada bulan Febuari 2019 di SMA Negeri 7 Padang ditemukan bahwa masih sedikitnya peminat dari peserta didik kelas XI yang ingin mengikuti kegiatan pembelajaran renang. dikarenakan ada beberapa aspek dan faktor yang mendukung minat belajar, salahsatunya yaitu (1) Guru yang berkualitas. Hal ini sejalan dengan pendapat Noor (2019) (2) Gizi yang seimbang, (Lesmana, 2018) (3) aspek motivasi dimana motivasi belajar ini berada pada dorongan pisikis yang timbul dari dalam diri (Sin \& Hudayani, 2020) dan dari faktor intrinsik dan faktor ekstrinsik. Dimana faktor intrinsik digolongkan atas beberapa aspek yaitu (1) Motif dalam keperibadian seseorang, (2) Sikap dalam mengambil keputusan, (3) Permainan, (4) Pengalaman dalam proses mengenal lingkungan fisik, (6) Tanggapan dalam melakukan pengamatan, (7) Persepsi proses untuk mengidentifikasi permasalahan pada objek (Suharyat, 2009). Hal ini berpengaruh pada pengembangan minat peserta didik terhadap olahraga renang.

Minat merupakan suatu dorongan yang sangat terikat pada perhatian dari masing - masing orang pada objek tertentu seperti benda, pekerjaan dan orang (Maulani, 2011). Minat sendiri sangat besar pengaruhnya pada pembelajaran, apabila bahan pelajaran yang tidak seseui dengan minat peserta didik maka akan tidak akan efektif dalam pembeajarannya (Baidawi, 2019). Salah satu indikator yang dapat melihat gambaran umum tentang minat peserta didik, bisa dilihat pada hasil belajar mereka melalui hasil ujian harian dalam pembelajaran penjas di keterampilan renang. Rata-rata nilai peserta didik XI MIPA di bawah KKM cukup banyak. Meskipun rata-rata siswa kelas XI MIPA lebih tinggi dari pada KKM (82,05) kelas XI IPS yang di bawah KKM $(67,00)$ Sedangkan rata-rata nilai peserta didik kelas XI IPS yang di atas KKM $(83,00)$. Secara akademik nilai ulangan harian semua peserta didik itu sangat rendah yang menunjukkan bahwa peserta didik belum sepenuhnya memahami materi renang. Berdasarkan hasil wawancara dengan guru penjas di SMA 7 Padang diketahui bahwasa renang ialah salah satu materi yang tercantum dalam kurikulum 2013. Dalam pelaksanaannya materi renang dilakukan dengan pemantapan aspek kognitif dan aspek psikomotor. Pelaksanaan materi ini haruslah ditunjang dengan sarana dan prasarana yang mendukung, seperti adanya kolam renang. Sarana dan prasarana untuk materi renang di SMA 7 Padang belum maksimal. Hal ini terlihat dari belum adanya kolam renang dan fasilitas perlengkapan renang di sekolah tersebut. Dari permasalahan di atas perlu dikaji terkait Tinjauan minat peserta didik kelas XI terhadap pembelajaran olahraga renang di SMA Negeri 7 Padang.

\section{METODE}

\section{Jenis Penelitian}

Jenis penelitian yang akan digunakan yaitu penelitian deskriptif. penelitian deskriptif adalah penelitian yang menjelaskan kejadian di lapangan dalam suatau wilayah.. Sesudah lengkapnya data yang dikumpulkan, kemudian data yang terkumpul akan disimpulkan (Arikunto, 2010). 


\section{Variabel Penelitian}

Menurut Cariabel adalah atribut, sifat, atau nilai orang, objek, atau aktivitas yang mengalami perubahan tertentu yang ditentukan oleh peneliti untuk dipelajari dan kemudian ditarik kesimpulannya.Variabel dalam penelitian ini yaitu minat peserta didik kelas XI dan pembelajaran olahraga renang di SMA Negeri Padang.

\section{Populasi dan Sampel Penelitian}

Populasi dalam penelitian ini yaitu seluruh siswa yang belajar di kelas XI SMA Negeri 7 Padang. Sebanyak 324 siswa kelas XI yang terdaftar pada tahun pelajaran 2019/2020 yang meliputi 9 kelas. Teknik pengambilan sampel dalam penelitian diambil menggunakan teknik simple random sampling. Menurut Sugiyono (2014) Teknik pengambilan sampel acak sederhana merupakan teknik pengambilan sampel sederhana karena pengambilan sampel anggota dari populasi dilakukan secara acak, terlepas dari kelas yang ada dalam populasi tersebut. Menurut pendapat Arikunto (2006), yaitu Jika populasinya kurang dari 100 orang, yang terbaik adalah mengambil semuanya; Namun, jika populasinya lebih dari 100 orang, maka $10-15 \%$ atau $20-25 \%$ harus diambil.

\section{Instrumen Penelitian}

Alat untuk pengumpulan data menggunakan kuesioner. Cara pengambilan data dalam pengumpulan data menggunakan Quesioner dilakukan dengan cara memberi seperangkat pertanyaan atau pernyataan tertulis kepada responden untuk dijawabnya (Sugiyono, 2012). Alat yang digunakan dalam penelitian ini adalah kuisioner yang berisi pernyataan-pernyataan yang akan digunakan dalam penelitian yang bertujuan untuk memulai dari dua faktor yaitu faktor internal (minat, perhatian dan aktivitas) dan faktor eksternal (lingkungan dan alat/kenyamanan). Penelitian ini menggunakan kuesioner tertutup.

\section{Data dan Sumber Data}

Jenis data dalam penelitian ini adalah data mentah dan data pembantu. Data utama yang terlibat adalah data yang diperoleh langsung peneliti dari narasumber berupa informasi yang diberikan dalam menjawab pertanyaan berupa kuesioner penelitian dan hasil observasi adalah "Minat Peserta didik Kelas XI Terhadap Pembelajaran Olahraga Renang di SMA Negeri 7 Padang', Data sekunder merupakan data yang diperoleh dari file siswa yang berasal dari data administrasi SMA Negeri 7 Padang tahun 2019/2020.

\section{Teknik Analisis Data}

Teknik analisis yang dapat digunakan adalah teknik distribusi frekuensi (statistik deskriptif) untuk perhitungan persentase "Bila suatu penelitian bertujuan mendapatkan gambaran atau menemukan suatu sebagaimana adanya tentang suatu objek yang diteliti maka teknik analisis yang dibutuhkan cukup dengan perhitungan persentase'. Rumus menghitung persentase yaitu:

$$
P=\frac{f}{n} \times 100 \%
$$

Sumber : (Sudijono, 2012)

Menurut Riduwan (2011), dalam pemberian makna yang berada pada skor yang sudah dibuat dan sudah dikelompokan menurut tingkatan yang ada. 
Tabel 1. Rentang Nilai

\begin{tabular}{cll}
\hline No. & \multicolumn{1}{c}{ Rentang Nilai } & \multicolumn{1}{c}{ Kategori } \\
\hline 1 & $81 \%-100 \%$ & Sangat Kuat \\
2 & $61 \%-80 \%$ & Kuat \\
3 & $41 \%-60 \%$ & Cukup \\
4 & $21 \%-40 \%$ & Lemah \\
5 & $0 \%-20 \%$ & Sangat Lemah \\
\hline
\end{tabular}

\section{HASIL}

Penelitian ini dilaksanakan secara online. Data mengenai minat peserta didik dalam pembelajaran renang dinilai denagn sub variable internal yaitu: Motif, Sikap, Permainan, Pengalaman, Tanggapan, Persepsi dan sub variable eksternal yaitu:

\section{a) Indikator Motif}

Pada indeks motivasi ditemukan jumlah jawaban "sangat setuju" sebanyak 102 jawaban (31,38\%,) "setuju" Jumlah jawabannya 89 jawaban $(27,38 \%), 85$ jawaban $(26,15 \%)$ menyatakan "ragu-ragu", 41 jawaban (12.62\%) menyatakan "tidak setuju ", dan sebanyak 8 jawaban "sangat tidak setuju" (2.46\%). Minat belajar peserta didik dalam pembalajarn renang dilihat dari skor ideal yakni 74,52\%, yang tergolong pada klasifikasi "Kuat/Baik".

\section{b) Indikator Sikap}

Pada indikator sikap ditemukan jumlah jawaban yang menyatakan "sangat setuju" sebanyak 123 jawaban (37,85\%). Jumlah jawaban yang menyatakan "setuju" sebanyak 102 jawaban (31,38\%), jumlah jawaban yang menyatakan "ragu" sebanyak 52 jawaban (16\%), jumlah jawaban yang menyatakan "tidak setuju” sebanyak 32 jawaban $(9,85 \%)$, dan yang menyatakan "sangat tidak setuju" 16 jawaban $(4,92 \%)$. Skor ideal dari indikator motif adalah $77,48 \%$ yang tergolong dikatagori nilai $61 \%-80 \%$ berada pada klasifikasi "Kuat/Baik".

\section{c) Indikator Permainan}

Berdasarkan uraian indikator minat permainan, ditemukan jumlah jawaban "sangat setuju" sebanyak 101 (31.08\%), dan jumlah jawaban "setuju" adalah 126 jawaban (38,77\%), 79 jawaban (24,31\%) menyatakan "ragu-ragu", 15 jawaban (4,62\%) menyatakan "tidak setuju", dan sebanyak 4 "sangat tidak setuju" Jawaban (1,23\%). Skor ideal dari indikator permainan adalah $78,77 \%$ yang tergolong dikatagori nilai $61 \%$ $80 \%$ berada pada klasifikasi "Kuat/Baik".

\section{d) Indikator Pengalaman}

pada indikator pengalaman, ditemukan jumlah jawaban "sangat setuju" sebanyak 101 jawaban (31.08\%), dan jumlah jawaban "setuju" sebanyak 112 jawaban $(34,46 \%)$, 76 jawaban $(23,38 \%)$ menyatakan "ragu-ragu", 28 jawaban $(8,62 \%)$ menyatakan "tidak setuju", dan maksimal 8 jawaban menyatakan "sangat tidak setuju" $(2,46 \%)$. Skor ideal indikator pengalaman adalah 76,62\%, yang tergolong dikatagori nilai $61 \%-80 \%$ berada pada klasifikasi "Kuat/Baik". 


\section{e) Indikator Tanggapan}

Pada indikator jawaban ditemukan jumlah jawaban "sangat setuju" sebanyak 103 jawaban (39.62\%), dan jumlah jawaban "setuju" ada 81 jawaban (31,15\%), jumlah jawaban yang mengatakan "mencurigakan" adalah 57 jawaban (21.92\%), jumlah yang mengatakan "tidak setuju" adalah 19 jawaban (7,31\%), jumlah yang mengatakan "sangat tidak setuju" nihil. Skor ideal pada indikator tanggapan adalah 80,62\% yang tergolong dikatagori nilai $81 \%$ - 100\% berada pada klasifikasi "Sangat Kuat/Sangat Baik".

\section{f) Indikator Persepsi}

Pada indikator persepsi, ditemukan jumlah jawaban yang mengatakan "sangat setuju" sebanyak 120 jawaban $(49,15 \%)$, jumlah jawaban yang mengatakan "setuju" sebanyak 92 jawaban (35,38\%), jumlah jawaban yang mengatakan "ragu-ragu" sebanyak 36 jawaban (13,85\%), jumlah yang mengatakan "tidak setuju" sebanyak 12 jawaban $(4,62 \%)$, jumlah orang yang menjawab "sangat tidak setuju" nihil. Skor ideal dari indikator persepsi adalah84,62\% yang tergolong dikatagori nilai $81 \%-100 \%$ berada pada klasifikasi "Sangat Kuat/Sangat Baik".

\section{g) Indikator Lingkungan Fisik}

Indikator minat lingkungan jasmani, didapatkan tingkat jawaban "sangat setuju" sebanyak 65 jawaban (33,33\%), dan jawaban setuju 33,33\% Sebanyak 54 jawaban $(27,69 \%)$, jumlah jawaban yang mengatakan "mencurigakan" sebanyak 48 jawaban (24,61\%), jumlah yang menjawab "tidak setuju" sebanyak 120 jawaban (10,5\%), dan jumlah yang mengatakan "sangat tidak setuju" adalah "lebih banyak Hingga 8 jawaban $(4,10 \%)$. Skor ideal indikator persepsi adalah $75,18 \%$ yang tergolong dikatagori nilai $61 \%$ - $80 \%$ berada pada klasifikasi "Kuat/Baik".

\section{h) Indikator Lingkungan Sosial}

Indikator lingkungan sosial, ditemukan jumlah jawaban "sangat setuju" sebanyak 256 (32,82\%) yang menunjukkan jawaban "setuju" jumlah 279 jawaban (35,77\%), jumlah jawaban yang menyatakan "ragu-ragu" sebanyak 185 jawaban $(23,72 \%)$, jumlah jawaban yang menyatakan "tidak setuju" sebanyak 42 jawaban (5,38\%), "sangat tidak setuju" ada 18 jawaban (2,31\%). Skor ideal indikator lingkungan sosial adalah 78,28\% yang tergolong dikatagori nilai $61 \%$ - $80 \%$ berada pada klasifikasi "Kuat/Baik".

\section{i) Keseluruhan Indikator}

Keseluruhan indikator ditemukan 971 jawaban menyatakan "sangat setuju" (34,74\%), dan 935 jawaban menyatakan "setuju" Jawaban (33,45\%), jumlah jawaban yang mengatakan "mencurigakan" sebanyak 618 jawaban $(22,11 \%)$, jumlah jawaban "tidak setuju" adalah 209 jawaban (7,48\%), jumlah jawaban "sangat tidak setuju" sebanyak 62 jawaban (2.22\%). Keseluruhan indikator mmemperoleh skor ideal 78,20\%. Menurut Riduwan (2011) yang tergolong dikatagori nilai $61 \%$ - 80\% berada pada klasifikasi "Kuat/Baik". 


\section{PEMBAHASAN}

Tujuan dari Penelitian adalah melihat minat peserta didik pada kelas XI MIPA dan IPS di SMA Negeri 7 Padang dalam melakukan kegiatan pembelajaran olahraga renang, di lihat dari faktor internal dan eksternal. Berdasarkan analisis di atas, diperoleh skor capaian sebanyak 10929 sedangkan skor ideal 13975. Bisa disimpulkan bahwa dari hasil penelitain Tinjauan Minat Peserta Didik Terhadap Pembelajaran Olahraga Renang di SMA Negeri 7 Padang sebesar 78,20\%. Dari hasil tersebut dari minat peserta didik sudah tinggi, akan tetapi belum mencapai level maksimal.

Olahraga adalah aktivitas gerak manusia yang dilakukan secara sadar melalui olah raga yang efektif dan meningkatkan kualitas tubuh manusia (Mardela, 2016), selain itu olahraga menjadi kebutuhan pada masyakarat dengan tujuan untuk mendapatkan kesehatan, kebugaran jasmani dan kesenangan (Neldi, 2018), oleh karena itu manusia dianggap sebagai unit fisiologis dan psikologis yang kompleks. Cabang Olahraga renang sangat disenangi oleh kalangan masyakat umum (Diet, 2019). Olahraga renang merupakan olahraga yang membutuhkan sarana dan prasara yang cukup banyak seperti Swimwear (pakaian renang), Kacamata Renang, Swim Cap (Penutup Kepala), Car Plugs (Penutup Telinga), Fins (sepatu katak), Hand Paddle(dayung tangan), Pelampung Seluncur, Pullbuoy (Moya, 2019). Menurut Alnedral (2016) Olahraga dalam Pendidikan jasmani merupakan pembelajaran yang sangat penting untuk pembentukan karakter bagi manusia seutuhnya. Dengan adanya pendidikan jasmani peserta didik di ajarkan bagaimana pola hidup sehat yang baik dan diajarkan karakter seperti Afektif (sikap), Kognitif (pengetahuan) maupun Psikomotorik (keterampilan).

Olahraga renang juga merupakan olahraga yang membutuhkan kemampuan seperti kelentukan kaki, kekuatan tangan, daya tahan, kecepatan, dan kecerdikan, selain itu olaharag renang merupakan cabang olahraga yang berkembang dilihat dari sarana dan prasarana dan organisasi serta club (Denay, 2019). Dari semua kemampuan dan kebutuhan itu dapat ditingkatkan melalui latihan fisik dan mental yang teratur. Banyak orang yang bisa berenang tetapi hanya sebatas renang biasanya, dan tidak menggunakan teknik yang semestinya dilakukan (Wickersham et al., 2020).

Dari hasil penelitian menunjukan bahwa olahraga renang cukup diminati oleh peserta didik kelas XI SMA Negeri 7 Padang, dengan persentasi 78,20\%. Persentasi ini menunjukan dari minat peserta didik terhadap pembelajaran olahraga renang belum begitu maksimal. Berdasarkan hasil wawancara yang dilakukan dengan beberapa peserta didik SMA Negeri 7 Padang terkait hubungan minat dan nilai peserta didik, menunjukan bahwa peserta didik memiliki minat yang tinggi terhadap pembelajaran olahraga renang, namun hasil ini tidak sebanding dengan nilai yang mereka dapatkan. Hasil nilai dari peserta didik rata - rata masih dibawah KKM hal ini dipengaruhi oleh faktor kesiapan/mental dari peserta didik itu sendiri dalam menghadapi ujian, seperti yang dikatakan Barrett (2013) bahwasannya masih banyak yang harus dilakukan untuk menumbuhkan mental seseorang dengan memberikan pembelajaran untuk meningkatkan mental seseorang. Metode yang digunakan guru pada proses pembelajaran jus belum sepenuhnya membantu peserta. Oleh karena itu hasil dari 
angket dan wawancara yang dilakukan kepada peserta didik menunjukan bahwa minat peserta didik yang tinggi dipengaruhi oleh beberapa faktor, baik secara internal maupun eksternal, namun disisi lain minat tidak menjamin hasil nilai yang didapatkan peserta didik tinggi. Hal ini dikarenakan adanya faktor lain yang mempengaruhi seperti kurangnya pemahaman peserta didik terhadap materi dan kurang mendukungnya metode pembelajaran yang digunakan oleh guru (Lesmana, 2017).

\section{KESIMPULAN}

Berdasarkan analisis data penelitian dan pembahasan hasil penelitian terkait minat peserta didik kelas XI terhadap pembelajaran olahraga renang di SMA Negeri 7 Padang, disimpulkan bahwa minat peserta didik terhadap pembelajaran olahraga berada pada katagori cukup "Kuat/Baik" dengan pencapaian persentasi sebesar 78,20\%. Hal ini sejalan dengan hasil wawancara yang dilakukan pada peserta didik, dimana peserta didik memiliki minat yang tinggi terhadap pembelajaran renang. Namun nilai yang didapatkan masih berada dibawah KKM dikarenakan beberapa faktor seperti kurangnya pemahaman peserta didik terhadap materi dan kurang tepatnya metode pembelajaran yang digunakan guru pada proses pembelajaran. Peneliti merekomendasikan untuk memperbaiki metode pembelajaran guna meningkatkan hasil pembelajaran, disamping itu untuk meningkatkan minta peserta didik dalam belajar renang diperlukan peningkatan dari beberapa faktor yaitu dari sarana dan prasarana disekolah.

\section{DAFTAR PUSTAKA}

Alnedral. (2016). Strategi Pembelajaran Pendidikan Jasmani, Olaharga dan Kesehatan. 2.

Arikunto, S. (2006). Prosedur Penelitian Suatu Pendekatan Parktik. Rineka Cipta.

Arikunto, S. (2010). Prosedur Penelitian Suatu Pendekatan Praktik. Rineka Cipta.

Baidawi, T. (2019). Minat Siswa Terhadap Pembelajaran Bolavoli Thoriq. Jurnal Patriot, 1300-1306.

Barrett, P. (2013). Nursing Education in Waterless Swimming Practice: A critical perspective on mental health experiences for adult nursing students. 13, 487-491. https://doi.org/10.1016/j.nepr.2013.05.002

Denay, N. (2019). Kontribusi Kemampuan Daya Ledak Otot Tungkai Terhadap Kecepatan Renang 50 Meter Gaya Dada Atlet Renang Kota Padang Naluri. Sain Olahraga Dan Pendidikan Jasmani, 19(2), 101-108.

Diet, A. (2019). Keterampilan Profesional; Penilaian \& Diagnosis Nutrisi; Terapi $\begin{array}{llll}\text { Nutrisi Medis Pelathan, } & \text { 119(September), } & 2019 .\end{array}$ https://doi.org/10.1016/j.jand.2019.06.086

Ilham. (2016). Latihan Poliometrik terhadap Kemampuan dan Keterampilan Shooting 
Free Throw Bolabasket (Studi Eksperimen Pada Mahasiswa FIK Univ. Jambi). Performa Olahraga, 1(2), 187-204.

Krisna, B. (2008). Contribution of Arm Muscle Strength and Leg Muscle Strength to FIK Students' 50 Meter Freestyle Swimming Ability. 131-138.

Lankia, T., Neuvonen, M., \& Pouta, E. (2019). Effects of water quality changes on the recreation benefits of swimming in Finland: Combined travel cost and contingent behavior model. Water Resources and Economics, 25, 2-12. https://doi.org/10.1016/j.wre.2017.10.002

Lesmana, H. S. (2017). Olahraga Sebagai Upaya Preventif Osteoporosis Dini. Jurnal Performa Olahraga, 32-41.

Lesmana, H. S. (2018). Profil Glukosa Darah Sebelum, Setelah Latihan Fisik Submaksimal dan Selelah Fase Pemulihan Pada Mahasiswa FIK. 8.

Maidarman. (1999). Kontribusi Kekuatan Otot Tungkai, Kelentukan Pinggang, Dan Keseimbangan Terhadap Kemampuan Start Renang Gaya Kupu-Kupu Pada Mahasiswa. Performa, 147-156.

Maidarman. (2010). Evaluasi Pelaksanaan Program Pendidikan Jasmani Sekolah Lanjutan Tingkat Pertama di Kota Padang. Performa, 49-59.

Mardela, R. (2016). Keterampilan Gerak Dasar Siswa Paud Kota Padang. Performa, 206-222.

Masrun. (2016). Pengaruh Mental Toughness Dan Motivasi Berprestasi Terhadap Prestasi Olahraga Atlit PPLP Sumbar. Jurnal Performa Olahraga, 1-11.

Maulani, I. (2011). Minat Siswa Belajar Pendidikan Jasmani Olahraga dan Kesehatan Ihsan. Jurnal Patriot, 1077-1086.

Moya, A. (2019). Renang berkelanjutan meningkatkan kapilasi otot putih dan pertumbuhan dengan hiperplasia pada ikan air tawar gilthead (Sparus aurata) fi omelan. 501, 397-403. https://doi.org/10.1016/j.aquaculture.2018.10.062

Neldi, H. (2018). Kontribusi Status Gizi Terhadap Kesegaran Jasmani. Performa, 6069.

Noor, M. (2019). Guru Profesional dan Berkualitas. ALPRIN.

Putra, A. Y., \& Lesmana, H. S. (2016). Perbedaan Pengaruh Pemulihan Aktif Dan Pemulihan Pasif Di Air Hangat Terhadap Penurunan Kadar Asam Laktat Setelah Aktivitas Fisik Submaksimal. Jurnal Performa Olahraga, 1((02)), 93-106.

Riduwan. (2011). Pengantar Statistik Untuk Penelitian Pendidikan, Sosial, Ekonomi, 
Komunikasi, dan Bisnis. Alfabeta.

Sato, D. D. (2020). Brain Research Superior Sensorimotor Behavior in Aquatic Environments. 395, 1-11. https://doi.org/10.1016/j.bbr.2020.112835

Sin, T. H., \& Hudayani, F. (2020). S tudi motivasi siswa dalam mengikuti pembelajaran pendidikan jasmani olahraga kesehatan. 5, 30-34. https://doi.org/10.23916/08588011

Siregar, G., \& Syahara, S. (2019). Perbandingan Tes Vertical Jump Dan Standing Broad Jump Terhadap Jarak Luncuran Pada Start Renang Gaya Bebas. Patriot, 139-144.

Sudijono, anas. (2012). Pengantar Statistik Pendidikan. Rajawali Pres.

Sugiyono. (2012). Metode Penelitian Kuantitatif Kualitatif dan R\&D. Bandung:Alfabeta.

Sugiyono. (2014). Cara Mudah Menyusun Skripsi, Tesis, dan Disertasi. Alfabeta.

Suharyat, Y. (2009). Hubungan Anatara Sikap, Minat dan Perilaku Manusia. Region, vol 1.

Syahputra, N., \& Arwandi, J. (2014). Persepsi Masyarakat Kota Padang Terhadap Olahraga Renang di Kota Padang. Patriot, 164-170.

Tavakolizadeh, J. (2012). The effect of swimming on the self-concept of female high school students. 69, 1226-1233. https://doi.org/10.1016/j.sbspro.2012.12.055

Wahyudi, D. (2019). Motivasi Berprestasi Atlet Sepakbola Jordus FC Kota Batusangkar. Pendidikan Olahraga, 2(1), 126-130.

Wickersham, A., Sugg, H. V., Epstein, S., Stewart, R., Ford, T., \& Downs, J. (2020). Systematic Review and Meta-Analysis: The Association Between Child and Adolescent Depression and Later Educational Attainment. In Journal of the American Academy of Child \& Adolescent Psychiatry. American Academy of Child \& Adolescent Psychiatry. https://doi.org/10.1016/j.jaac.2020.10.008 